\title{
The Past, History, and Corporate Social Responsibility
}

\author{
Robert Phillips ${ }^{1} \cdot$ Judith Schrempf-Stirling ${ }^{2}\left(\mathbb{D} \cdot\right.$ Christian Stutz $^{3,4} \mathbb{0}$
}

Received: 16 September 2019 / Accepted: 15 October 2019 / Published online: 5 November 2019

(c) Springer Nature B.V. 2019

\begin{abstract}
An emerging body of research recognizes the importance of the past and history for corporate social responsibility (CSR) scholarship and practice. However, the meanings that scholars and practitioners can ascribe to the past and history differ fundamentally, posing challenges to the integration of history and CSR thinking. This essay reviews diverse approaches and proposes a broad conceptualization of the relationship between the past, history, and CSR. We suggest historical CSR as an umbrella term that comprises three distinct theoretical perspectives. The "past-of-CSR" perspective is concerned with the history of CSR and business ethics as a set of concepts and practices. The "past-in-CSR" perspective involves employing empirical historical research to substantiate and elaborate CSR concepts and theories. Finally, the "past-as-CSR" perspective seeks to understand the past as a living, yet contested, facet of current organizations, influencing contemporary perceptions of corporate and managerial responsibility. We then elaborate on conceptual issues and paths that may prove useful for future research. In all, this essay and the thematic symposium it precedes strive to deepen and broaden the salience of the past and history for thinking about business ethics and business responsibilities.
\end{abstract}

Keywords Corporate social responsibility · Business ethics · Historic corporate social responsibility · Historical research · Organizational history $\cdot$ Uses of the past

Part of a broader literature dedicated to more historically informed theory and practice (Kipping and Üsdiken 2014; Maclean et al. 2016; Rowlinson et al. 2014; Stutz and Sachs 2018; Wadhwani and Bucheli 2014), the concept of historic corporate social responsibility (HCSR) addresses questions of responsibility and accountability for long-ago actions (Schrempf-Stirling et al. 2016). HCSR considers how corporations manage the legitimacy of their activities when criticism of past wrongdoings flares up. The introduction of HCSR to the scholarly discourse about business ethics and

Robert Phillips

rphillips@schulich.yorku.ca

Judith Schrempf-Stirling

judith.schrempf-stirling@unige.ch

Christian Stutz

christian.stutz@fh-hwz.ch

1 Schulich School of Business, York University, Toronto, Canada

2 University of Geneva, Geneva, Switzerland

3 University of Applied Science in Business Administration Zurich, Zurich, Switzerland

4 University of Jyväskylä, Jyväskylä, Finland business responsibilities can "be seen as marking a historic turn in the ever-expanding field of CSR" (Godfrey et al. 2016, p. 601, italics added). The idea that the past and history have relevance for CSR scholarship, however, is a central theme of a more diverse body of research (Stutz 2018).

A first camp values a deep and complex understanding of the history of CSR practice and thought (e.g., Carroll et al. 2012; Kaplan and Kinderman 2017; Marens 2010, 2012, 2013), in order to revitalize today's CSR thinking by "build[ing] new bridges from the past to the present" (Stutz 2018, p. 21). The second group of scholars appreciates prior historical periods as a "fervid laboratory of social innovation" (Husted 2015, p. 138) or a rich empirical repository of corporate misconduct among other topics of interest to CSR scholars. This camp uses history as a methodological approach to contribute to recent theoretical debates (e.g., Acosta and Pérezts 2019; Djelic and Etchanchu 2017; Marens 2018; Stutz and Sachs 2018; Warren and Tweedale 2002). This research interest follows a more general development in the broader management and organization studies, where the use of historical methods, evidence, and reasoning is increasingly considered a legitimate methodological option for business scholarship 
(Kipping and Üsdiken 2014; Maclean et al. 2016; Rowlinson et al. 2014; Van Lent and Durepos 2019; Wadhwani and Bucheli 2014). Finally, a third camp of research shares Schrempf-Stirling et al.'s (2016) interest in the contemporary relevance of the past for the (ir)responsible management of organizations in the present (e.g., Booth et al. 2007; Brunninge and Fridriksson 2017; Mena et al. 2016; Janssen 2013; Stutz and Schrempf-Stirling 2019).

This emerging - and manifestly diverse - body of CSR research affirms the importance of taking the past and history seriously. A simple definition of history conceives it as the interpretation and representation of the past from a position in the present (Rowlinson et al. 2014), regardless of whether mobilized by corporations and managers, stakeholders, social actors, the state, or academic scholars. However, recent literature that aims to justify a place for "Clio [the muse of history] in the business school" (Perchard et al. 2017, p. 1) provides a note of cautionintegrating history into disciplinary scholarship "requires [both] new ways of acting and [...] thinking." (Wadhwani and Bucheli 2014, p. 23, italics in original). CSR and business ethics academics interested in the past should not underestimate the conceptual and methodological challenges that historical thinking and acting pose (Stutz 2018). Consider, for instance, that Schrempf-Stirling et al. (2016) think differently about the past than Carroll et al. (2012) who provide one of the more influential-if US-centric-histories of CSR. While the former hold an interpretive historical stance to show both the symbolic and substantive relevance of the past in the socially constructed present, the latter retell the past from an objective position to illuminate the provenance of present thoughts and practices.

As another methodological challenge, one needs to recognize that the practice of history might have some similarities to other qualitative approaches, yet the temporal distance creates fundamental onto-epistemological differences in research and writing (Rowlinson et al. 2014). As a result, business ethics and CSR scholars grappling with the past risk "historical dilettantism" by failing to meet appropriate scholarly standards in historical thinking and practice (Maclean et al. 2016, p. 616).

Anticipating both the prospects for-and challenges torealizing the full potential of the past and history to CSR scholarship, this thematic symposium seeks to deepen and broaden the salience of the past for thinking about business ethics and business responsibilities. With this essay, we aim to take stock of the several nascent and emerging conversations at this moment in time as well as provide avenues for future research. In particular, we propose a broad conceptualization of the relationship between the past, history, and CSR thinking and suggest using historical CSR as an umbrella term that draws together the various threads of research. Thereby we regard the notion of HCSR as a subset of the broader idea of historical CSR.

In what follows, we first present our three history perspectives: "past-of-CSR," "past-in-CSR," and "past-as-CSR". We also introduce the contributions of the individual articles of this thematic symposium to further the conversation. We conclude by elaborating future research directions for the most recent approach, the past-as-CSR perspective.

\section{Toward Three History Perspectives}

An emerging body of research affirms the past and history's relevance for CSR scholarship, yet ascribes different meanings to the central notions. We isolate three perspectives that embrace distinct understandings of the past and history. We follow Munslow's (2006) conceptualization of different ontological and epistemological positions on the matters of history and the past, as also expressed in Coraiola et al. (2015) and Suddaby and Foster (2017). One can think of the relationship as a continuum: On the one hand, scholars can equate the past and history (objectivism) and strive to understand the past "as it once was" (positivism). On the other hand, scholars may think of history as a narrative of the past that is tied to the narrator's position (subjectivism). In this view, history is largely malleable despite the "brute facts" of the past (constructivism). It is this variety of past and history relationships that inform our three perspectives. Table 1 summarizes the different conversations and perspectives, to which we refer in our discussion below.

\section{Past-of-CSR: History of CSR Thought and Practice}

Research within the past-of-CSR perspective strives for a more comprehensive understanding of the history of CSR thought and practice. Research of this genre is concerned with producing historical knowledge about the idea of business ethics and business responsibility. According to Stutz $(2018$, p. 3), this kind of historical knowledge may serve as a source of "historical consciousness" (Suddaby 2016) or historical awareness that may engender critical reflection on the power structures and sedimented relations in which historical and contemporary patterns of CSR are embedded.

Stutz's recent review (2018) synthesizes existing research to provide historical depth to the received scholarly narrative about CSR. Many scholars consider the origins of CSR as associated with the historical particularities of the nineteenth and twentieth century Anglo-American institutional and cultural setting (e.g., Abend 2013; Acquier et al. 2011; Carroll et al. 2012; Marens 2010, 2012, 2013). Going farther back in time, Hielscher and Husted (2019) examine the "proto-CSR" activities of mining guilds as far back as the thirteenth century. This extends, as well, to the more recent 


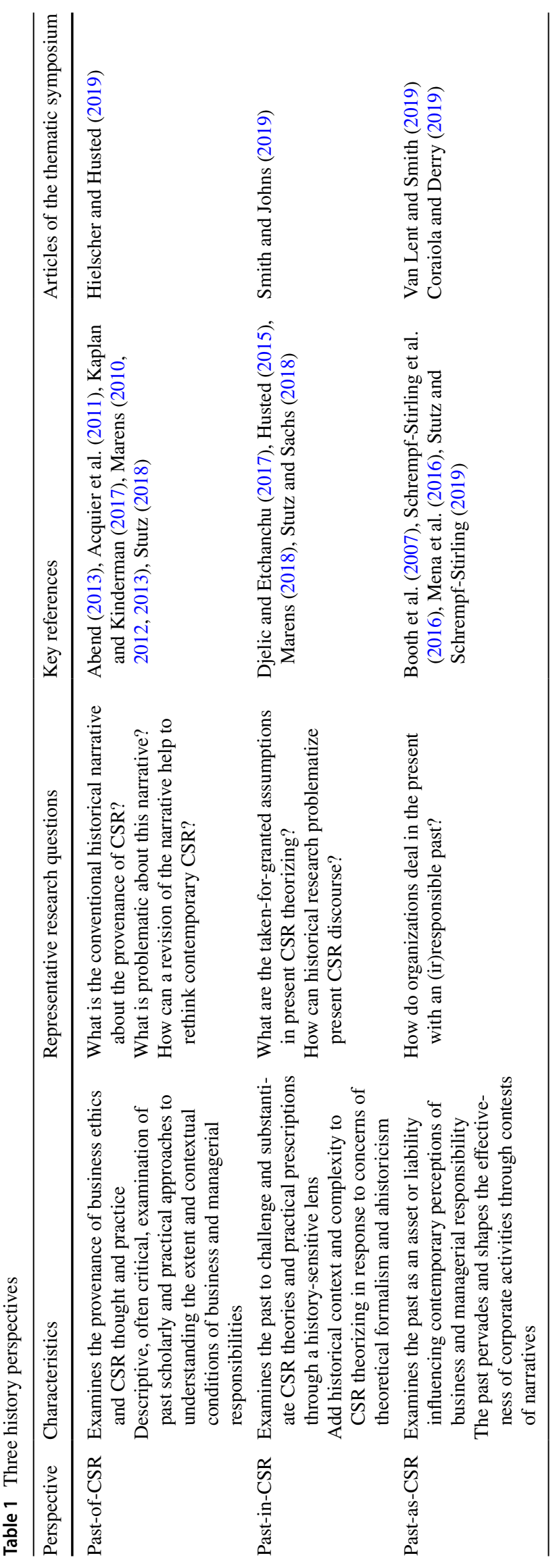


global diffusion (e.g., Kaplan and Kinderman 2017) of ethical thinking and practice in business (e.g., Antal et al. 2009; Bengtsson 2008; Ihlen and von Weltzien Hoivik 2013; Van Buren 2008).

However, Stutz (2018) presents the history of CSR thought and practice from three distinct meta-theoretical orientations towards CSR (viz., economic, critical, and politico-ethical lens). This contrast of distinct narrative accounts demonstrates how the mobilization of history also serves political purposes in the present (De Baets 2009). Stutz (2018, pp. 20-21) argues that prominent histories of CSR - written by scholars committed to the politico-ethical lens-tend to portray an "overly glossy" view that may neglect problematic aspects of CSR. Going further, critical scholars (Kaplan and Kinderman 2017; Marens 2010, 2012, 2013) provide historical evidence suggesting that CSR, as a business-led practice, may fail to provide adequate solutions-due, in part, to the perspective of their historical frame.

Leading scholars of organizational and management history argue that one explanation for the perceived dearth of novel ideas in management scholarship can be traced back to a limited view of the past that places boundaries around what scholars consider key foundations of management knowledge (Cummings et al. 2017). They go on to argue that a more nuanced historical understanding of how received management theories emerged and were enacted in the past can lead to more innovative and useful contemporary theory. As with the history of management theory more broadly, so also with the "past-of-CSR" perspective. Here we join Stutz's (2018, p. 20) call to "push the CSR community to become more historically conscientious" about its own scholarly past.

\section{Past-in-CSR: Historical Methods, Evidence, and Reasoning}

Whereas the previous perspective applies a historical lens to improve our understanding of past and present CSR theorizing, the past-in-CSR perspective involves tapping the potential for empirical historical research to exposit, substantiate, and even challenge CSR concepts and theories (Husted 2015; Marens 2018; Stutz and Sachs 2018). This genre of research draws from a new methodological paradigm within organization studies and the broader business disciplines to develop historical organization studies (Kipping and Üsdiken 2014; Maclean et al. 2016; Rowlinson et al. 2014; Wadhwani and Bucheli 2014). The literature associated with this paradigm provides practical guidance to the application of historical methods in an interdisciplinary context (e.g., Gill et al. 2018; Stutz and Sachs 2018) with an eye toward meeting the quality standards of both underlying disciplines (Maclean et al. 2016).
Toward this end, Husted (2015) argues that "historical material provides important resources for several current CSR issues and debates" (2015, p. 135). By reviewing historical work about industrial paternalism in the nineteenth century, Husted (2015) encourages political CSR scholars to investigate the role of firms in providing (putatively) governmental services in past contexts of institutional voids, sharing many features with today's emerging markets (i.e., boundary conditions). Warren and Tweedale (2002) suggest that business history can inform numerous ethical aspects of contemporary business including the operation of companies founded with a social conscience, green business and the environment, and the "discrepancy between the popular image of business as a highly respectable activity [...] and what can happen behind the scenes-power struggles, rivalry, the manipulation of information, and the pursuit of short-term ends" (2002, p. 215). Beets (2011) provides a helpful list of critical events in the ethics of U.S. corporate history that may motivate future past-in-CSR inquiries.

Beyond seeing the past as a repository of cases, Marens (2018) praises the advantages of history-work over the predominant scientific theory-testing mode of inquiry. Considering CSR scholars' concern with inequality within and between societies, he argues that historical-empirical methods are better suited to account for institutionally deep-rooted, change-resistant issues. As an exemplar of this type of study published in this volume, Smith and Johns (2019) use history to contextualize and better understand the current debate over modern slavery. Barros and Taylor's (2018) historical study of a significant Brazilian think tank in the 1960s provides another example. Addressing a gap in business ethics research on the influential role of think tanks on the transformation of social structures, they invoke this historical case to begin filling this gap.

Stutz and Sachs (2018) develop a methodological approach to the past that explicates yet another use of history to the CSR community. Recognizing this community's normative agenda to (re)shape business in directions more humane and just, they argue for history as a reflexive space for theory elaboration. On this understanding, historical research is a means of evaluating normative theoretical claims and elaborating them. Djelic and Etchanchu (2017) compare the contemporary conceptualization of political CSR with alternative historical patterns of business-society relationships. They demonstrate that current CSR is a form of business-society interaction that reflects a (neoliberal) ideology embedded in a particular time and place. This literature stream suggests that history can add historical context and complexity to CSR theorizing in order to allay concerns of theoretical formalism and ahistoricism. 


\section{Past-as-CSR Perspective: HCSR and the Living Past}

The past-as-CSR perspective seeks to understand the past as a living-and contested-facet of current organizations. This genre of research considers objective elements of the past (e.g., evidence of past (ig)noble activities) but highlights how contemporary actors, often with diverse interests, interpret and use the past in the present. The past pervades and shapes the effectiveness - even viability —of current business activities through contested interpretations of an organization's history. Such "contest of narratives" can lie dormant when there is general agreement about the contours and implications of the past. However, when new evidence emerges (e.g., when the Berlin Wall came down and evidence surfaced from the former East Germany concerning business activities under Soviet Communism) or changes in contemporary norms and values affect how existing historical evidence is perceived, interpretive contest can re-emerge. The papers in this volume examine the emergence of new evidence and how interpretation of the evidence-old and new-is influenced by evolving cultural norms and expectations (Van Lent and Smith 2019; Coraiola and Derry 2019).

Schrempf-Stirling et al. (2016) look closely at HCSR by examining the relationship between "claim legitimacy" (i.e., the legitimacy of moral claims raised about past wrongdoings against corporations) and its effect on "corporate legitimacy" (i.e., the generalized perception that the behavior of a corporation is appropriate within a particular institutional context) mediated through "corporate engagement" (i.e., the behavioral options of corporations when reacting to a contestation of their past). Corporate engagement ranges from no engagement with the historical claim or claimants, to denying the claim, to fully engaging in a public discourse on the claim with an eye toward possible reconciliation of the claims and (at least temporary) resolution of the interpretive contest. The effects of corporate engagement on the legitimacy of the firm depend on whether the level of corporate engagement was adequate, given the legitimacy of the claim and the histories of the contestants.

While the HCSR - and the past-as-CSR perspective, more generally - is relatively new, other research has contributed to this genre avant la lettre (e.g., Booth et al. 2007; Janssen 2013). Mena et al. (2016) consider the manipulative initiatives by organizations to shape how larger audiences view instances of past corporate wrongdoing. Stutz and Schrempf-Stirling (2019) provide conceptual definitions of (ir)responsible uses of the past by managers and present them as a matter of moral integrity. In doing so, they also connect to the lively conversations of the so-called "uses of the past" approach (Suddaby et al. 2010; Wadhwani et al. 2018), which has mostly avoided questioning the ethics of managerial history-work.
The past-as-CSR perspective-and Schrempf-Stirling et al.'s (2016) elaboration of HSCR, specifically-invites a number of fundamental questions. Some are addressed in the pages of this thematic symposium. Others await future studies. We consider both below.

\section{Contributions to the Thematic Symposium}

The first two articles incorporated in this volume focus on and expand Schrempf-Stirling's conceptualization of HCSR. Van Lent and Smith examine the Hudson's Bay Company's history-work over the long term as well as the public contestation of its past due to mistreatment of Canada's Indigenous people. This empirical study adds historical context and complexity to HCSR, so that the authors bridge our past-in-CSR (using history to theorize) and past-as-CSR (theorizing the past in the present) categories. Their main contributions are threefold: First, following the traces of the company's use of history in its stakeholder relations for almost 120 years, they observe other forms of historywork (mainly, heritage branding) that are simultaneously or sequentially employed in addition to corporate engagement with narrative contests of the past. Instead of assuming managerial discretion to choose between low and high engagement at $t_{0}$, they reveal the sedimented nature of corporate engagement where managers are constrained by previous forms of history-work of the company. Second, the study complicates the aspect of "the receptivity to historical criticism within the current context," which is a central aspect of Schrempf-Stirling's notion of claim legitimacy. Recognizing that corporations are increasingly exposed to fragmented institutional environments with conflicting stakeholder demands, they elaborate on claim legitimacy to embrace cases of ambiguous stakeholder pressures. Finally, the study considers new mechanism of narrative contests by depicting the interaction processes of ambiguous claim legitimacy and sedimented corporate engagement. They conclude that their elaboration "could lead firms to recognize inconsistent or cynical elements in their approach to history, which would in turn provide a basis for more consistently responsible corporate engagement with history" (Van Lent and Smith 2019).

Coraiola and Derry develop a historical case study of U.S. tobacco companies to explore how corporations engage in forgetting work to avoid taking responsibility for past misbehavior. They introduce to the HCSR discourse the notion of an ethics of remembering on an industry level and argue that "sustained efforts of forgetting work depend on the continuity of the project through various generations of employees, which presumes the existence of frameworks of remembering in place" (Coraiola and Derry 2019). They advance HCSR further by highlighting how a collective of corporations engages in forgetting work and how such efforts lead 
to "additional layers of historical irresponsibility and may turn into a compounded liability in the event the memory of the colletive strategy of social forgetting becomes public" (Coraiola and Derry 2019).

The next two articles in this volume exemplify the vast opportunities for empirical historical research to inform mainstream CSR discourses. Hielscher and Husted describe the pre-modern activities of medieval German miners' guilds as "proto-CSR." Starting from the premise that CSR is a modernist concept, their article is not a contribution to the past-of-CSR perspective per se, but it is clearly an example of the past-in-CSR. They elaborate on early-at the time novel and experimental-practices of mutual aid involving mining guilds. These practices evolved through the interactions among business, worker, ecclesiastical, and secular groups to form the precursors to many of our modern social and workplace institutions. If today's CSR practices have become rigid, standardized, and overly "Westernized," it may be due to the loss of pragmatic experimentalism and a neglect of the lessons of history.

Smith and Johns use a historical lens to engage with a social phenomenon that is of utmost humanist concern for business ethics and CSR scholars: slavery and racism. Empirically, they investigate the consumer market for slavery-free sugar in nineteenth-century Britain, discovering that this values-driven market category disappeared again in circa 1840 - despite the ongoing scourge of slavery. Following the principles of past-in-CSR, they challenge assumptions of scholars participating in academic discourse about modern slavery in which parallels and continuities with historical reactions to slavery are largely ignored. By historicizing modern slavery, the authors highlight the problem of overly optimistic historical meta-narratives that lead scholars to believe in the steady moral progress of humankind. Their documentation of this slippage in the arc of the moral universe away from justice adds historical nuance to contemporary thinking. Their theorization explains the demise of ethical consumption due to shifting attitudes towards slavery and the resurfacing of racism. By considering the fragile nature of ethics-driven market categories, they offer a note of caution to scholars and practitioners who place their hopes in the moral consciousness of consumers to tackle modern slavery.

\section{Avenues for Future Research}

As the past-as-CSR perspective is still emerging, we present here directions for future research that we consider promising. We first turn to prospective topics specific to HCSR, before discussing other, broader conceptual paths that may prove useful. Table 2 shows the research opportunities for both HCSR and other past-as-CSR research.

\section{Different Media}

Arguably the default raw materials of historical analysis are documentary. Historians are often imagined combing through dusty archives deep in the bowels of some library or other ancient structure. How thoughts, opinions, and directives were contemporaneously recorded is, indeed, a rich and nuanced source of historical insight. However, written records are far from the only source of insight and historical contest.

The recent debates about statues (e.g., Robert E. Lee throughout the American South), buildings (Georgetown University's Mulledy and McSherry Halls) and colleges (e.g., Yale's Calhoun College) have caused re-examinations of those so honored. Recognitions of place and the indigenous Traditional Custodians of the Land are becoming more frequent in Australia, Canada, and elsewhere.

To date, these eliminations and elevations more often occur in educational and governmental settings than within business firms. One notable example of using physical structures to represent and frame history is Haigh's (2007) Asbestos House-a historical examination of James Hardie

Table 2 Avenues for the past-as-CSR perspective

\begin{tabular}{|c|c|c|}
\hline Conceptual paths & Research opportunities & Key references \\
\hline $\begin{array}{l}\text { Legitimacy } \\
\text { (following the } \\
\text { lines of HCSR) }\end{array}$ & $\begin{array}{l}\text { How do companies react to re-examinations of physical manifestations of ignoble pasts } \\
\text { (e.g., statues)? } \\
\text { When and why does a company's history prevail over obscuration? } \\
\text { What are the responsibilities in acquiring organizations with a contested past? } \\
\text { How does the public react to mere symbolic memorialization of an ignoble past? }\end{array}$ & Schrempf-Stirling et al. (2016) \\
\hline $\begin{array}{l}\text { Identity, image, } \\
\text { and reputation }\end{array}$ & $\begin{array}{l}\text { How does an (ig)noble past influence corporate identity, image, or reputation? } \\
\text { Do distinct stakeholder groups prize an (ig)noble past differently? }\end{array}$ & Barnett et al. (2006) \\
\hline Legacy & $\begin{array}{l}\text { What is the motivation to create a lasting and positive legacy? } \\
\text { How do corporations make use of a positive legacy? }\end{array}$ & Suddaby (2016), Fox et al. (2010) \\
\hline Nostalgia & $\begin{array}{l}\text { How does the longing for the past by employees influence the evaluation of current CSR } \\
\text { practices? } \\
\text { What is the role of emotions in the evaluation of past wrongdoings? }\end{array}$ & Gabriel (1993), Davis (1979) \\
\hline
\end{tabular}


Industries' efforts to disavow legal, moral, and historical responsibility for asbestos-related illness and death. It will be interesting to see how companies react going forward to the non-documentary physical manifestations of their corporate histories.

\section{Acquiring an Inconvenient Past}

Managers interested in the effects of history on today's organizational practice may wonder about the durability of history. In many cases, managers would be justified in hoping that the re-emergence of a particular piece of their company's history will blow over if simply ignored. Public attention spans can be short, and many historical controversies amount to little more than flashes in the pan. But why? What are the factors that influence this durability?

When a newly emergent contest of narratives does prove durable, common reactions include re-branding or mergers with less controversial companies. Future research may fruitfully examine the effectiveness and moral justifiability of these tactics. When and why does a company's history prevail over obscuration? And how should we understand the responsibilities of acquiring organizations to address the history of acquired organizations?

\section{Action, Omission, Memorialization}

Asserting the priority of action over intention invokes historical questions of inaction. In assessing historical responsibility for inaction, intentions move to the background. IBM did not intend the Holocaust; Shell did not intend that Ken Saro-Wiwa be executed (Wheeler et al. 2002); and Nokia Siemens Networks did not intend for Iranian dissidents be tortured (Schrempf 2011). According to some, these corporations nevertheless fell short of meeting their responsibilities (Young 2006; Schrempf-Stirling and Palazzo 2016; Miller 2001) by failing to mitigate the harm they had the power to do so.

A corporation has moral responsibility for its actions and inactions if they were performed or omitted voluntarily and the corporation could have acted differently (Manning 1984; Werhane 1985). Coraiola and Derry (2019) demonstrate that an industry's forgetting work turns into a compound liability over the course of time when the irresponsible history-work becomes known to the public. Consider also the practice of "memorialization" of past wrongdoings. Corporate memorialization remembers aspects of the past, but such rituals can also signal a discontinuity, closure, and a break with the past (Suddaby and Foster 2017). As a paradoxical consequence, memorialization of past misconduct may take place only in the symbolic realm without any substantial efforts in terms of redemption.
This is where the historian's tool kit, specifically, historiography plays a role in assessing responsibility. How events and practices-including the history-work by corporations - are discussed and passed down over time provides clues and evidence of both the relative voluntariness of the action and the availability of alternatives. Articles of this volume started to evaluate current companies' responsibility for past activity through the historical lens, yet ample opportunities for historical research remain.

\section{Future Directions for the Past-as-CSR}

While HCSR primarily uses the concept of legitimacy to bridge the past, present, and future of corporations, CSR scholars interested in the contemporary relevance of the past could use other conceptual underpinnings and foundational past-related concepts. Within the humanities, the broader social sciences, and other business disciplines, scholars understand that the mobilization of the past in the present is multifaceted. Table 3 provides an overview of concepts of business studies that either emphasize the agency of organizational actors (e.g., rhetorical history) or the constraining forces of past events (e.g., imprinting). CSR scholars can "borrow" and adapt them to improve our understanding of past-as-CSR phenomena. We elaborate on this by considering related ideas of identity, image, reputation, legacy, and nostalgia.

\section{Corporate Identity, Image, and Reputation}

Corporate image, identity, and reputation are similar constructs. While some use the three terms interchangeably, other scholars have been eager to clarify how the concepts differ. Identity refers to how internal stakeholders perceive the corporation. As Fombrun (1996) and Barnett et al. (2006) argue, identity refers to the core character of a corporation and the features that appear most relevant to internal stakeholders (i.e., employees). Image, in contrast, relates to the desired or actual perception of a company by its external stakeholders (Alvesson 1998). According to Whetten (1997), a corporate image is the perception that corporations want their external stakeholders to have about them. Others maintain that the image is the actual perception of a company by external stakeholders. Hence, it can be positive or negative (depending on the stakeholder).

Reputation combines elements of both identity and image (Walker 2010). Fombrun's (1996, p. 72) definition of a firm's reputation is perhaps the most influential. Reputation is the "perceptual representation of a company's past actions and future prospects that describes the firm's overall appeal to all of its key constituents when compared with other leading rivals." Corporations can have multiple (or mixed, or both) 
Table 3 Examples of past-related concepts in the broader business discipline

\begin{tabular}{|c|c|}
\hline Concept & Description \\
\hline Brand heritage & $\begin{array}{l}\text { Brand heritage is defined as "a dimension of a brand's identity found in its track record, longevity, core values, use } \\
\text { of symbols and particularly in an organizational belief that its history is important. A heritage brand is one with } \\
\text { a positioning and a value proposition based on its heritage." (Urde et al. 2007, p. 4, italics in original) }\end{array}$ \\
\hline Imprinting & $\begin{array}{l}\text { As part of the notion of imprinting, Stinchcombe (1965) observed that "at founding, organizations are particularly } \\
\text { sensitive to adopting influences and characteristics from their external environment. Once adopted, these charac- } \\
\text { teristics tend to persist." (Suddaby and Foster 2017, p. 1965) }\end{array}$ \\
\hline Organizational forgetting & $\begin{array}{l}\text { Organizational forgetting comprises “ongoing deliberate omission of potentially contradictory aspects of the } \\
\text { organization's history (i.e., what we label 'structural omission') or the ongoing deliberate attempt to neutralize } \\
\text { these contradictory aspects with valued identity cues (i.e., 'preemptive neutralization')." (Anteby and Molnar } \\
2012 \text {, p. 516) }\end{array}$ \\
\hline Organizational historicising & $\begin{array}{l}\text { Organizational historicizing is a "temporal pattern of micro-level activities that accounts for how actors used [...] } \\
\text { historical material and, in doing so, lent the authenticity of history to their actions [...]." (Hatch and Schultz } \\
2017, \text { p. 1) }\end{array}$ \\
\hline Organizational memory & $\begin{array}{l}\text { Defined as "stored information from an organization's history [more precisely: the past] that can be brought to } \\
\text { bear on present decisions." (Walsh and Ungson 1991, p. 61) }\end{array}$ \\
\hline Organizational remembering & $\begin{array}{l}\text { "We term the process by which actors use both rhetoric and history to socially construct membership with an } \\
\text { organization, organizational remembering." (Suddaby et al. 2016, p. } 298 \text {, italics in original) }\end{array}$ \\
\hline Path dependence & $\begin{array}{l}\text { "In short, organizational path dependence can be defined as a rigidified, potentially inefficient action pattern built } \\
\text { up by the unintended consequences of former decisions and positive feedback processes." (Sydow et al. 2009, p. } \\
34 \text { ) }\end{array}$ \\
\hline Retro branding & $\begin{array}{l}\text { Retro branding is defined "as the revival or relaunch of a product or service brand from a prior historical period, } \\
\text { which is usually but not always updated to contemporary standards of performance, functioning, or taste." } \\
\text { (Brown et al. 2003, p. 20) }\end{array}$ \\
\hline Responsible history-use & $\begin{array}{l}\text { "Responsible use of the past is committed to an honest search for historical knowledge and acceptance of its pro- } \\
\text { visional nature." (Stutz and Schrempf-Stirling 2019, p. 10) }\end{array}$ \\
\hline Rhetorical history & $\begin{array}{l}\text { Rhetorical history is defined "as the strategic use of the past as a persuasive strategy to manage key stakeholders } \\
\text { of the firm." (Suddaby et al. 2010, p. 157) }\end{array}$ \\
\hline
\end{tabular}

reputations: Wal-Mart, for instance, has a reputation among its suppliers of being a tough negotiator, and a reputation of being good for customers and investors (Carter and Deephouse 1999). Reputations may also vary depending on the underlying institution: economic reputation, social reputation, environmental reputation.

More specific to historical concerns, Fombrun (1996) explains that reputation is the result of corporate past actions and future prospects. Reputation has "an accumulated historical meaning" (Chun 2005, p. 96) that "takes time to build" (Balmer 1998, p. 696). Reputation is relatively stable, but mutable (Mahon 2002; Rhee and Haunschild 2006). Recent work has emphasized that a strongly positive reputation may also increase both the vigilance and expectations of stakeholders (Parker et al. 2019). We suspect that the addition of historical responsibility considerations may fruitfully inform longstanding questions of corporate identity and reputation. Future inquiries, for instance, might pursue the question whether distinct stakeholder groups prize the (ig)noble past of a corporation differently over time. Prior research suggests that a long history in CSR is useful to manage current CSR crisis (Vanhamme and Grobben 2009). Also, can employers use the history of being first movers on a historically controversial issue to attract new employees?

\section{Legacy}

Suddaby (2016, p. 55) considers organizational legacy a bridging construct to integrate history and organization studies. An organization's unique historical legacy is a crucial variable in explaining aspects of corporate behavior. Fox et al. (2010, p. 159) stressed an important characteristic of legacy when they defined legacy as being "manifested in the impact that one has on others beyond the temporal constraints of the lifespan." Like reputation, legacy is based on perception, can vary by stakeholder, can be positive or negative, and is built over time. There remain differences between legacy and reputation, however. Unlike reputation, legacy is not comparative. Legacy is about creating enduring popularity and does not necessarily involve an outperformance of other actors. Legacy is also more enduring. Because legacy — unlike the broader concept of historical responsibility - is backward looking, the activities in question cannot be changed. The interpretation of these activities is subject to contest at any time (Schrempf-Stirling et al. 2016), but this is a slower process than changing a reputation.

Research on legacy has also appeared in psychology and focuses on how legacy affects individuals' activities, on the intensity of the legacy motive, and on legacy building 
behavior. Humans recognize their mortality and are eager to create meaning to their lives. Humans want to contribute positively to the world and ensure that their lives mattered. Psychology-based studies in management and business ethics have investigated the legacy motive in business contexts (Fox et al. 2010; Wade-Benzoni et al. 2010). The motivation to create lasting and mostly positive legacies encourages ethical decision-making and responsible behavior in a business context (Fox et al. 2010).

In their experiments, Wade-Benzoni et al. (2010, p. 7) found that "compared to benefits, allocating burdens intergenerationally increased concern with one's legacy, heightened ethical concerns, intensified moral emotions (e.g., guilt, shame), and led to feelings of greater responsibility for and affinity with future generations." Some legacy-related research found that the motivation to avoid a negative legacy is stronger than the motivation to create a positive legacy (Wade-Benzoni et al. 2010). Cognizant of the dangers inherent in directly adapting individual constructs to the group level, we argue that the considerations of legacy and sensitivity to the demands of historic responsibility more generally can be usefully employed in the case of corporations.

Executive's identification with the organization (Treviño et al. 2008) will increase concern for organizational legacy. Future research within the genre of past-as-CSR and legacy might explore what other factors influence the desire to maintain or repair a corporate legacy (founding actor, family name, length of tenure, level of seniority, age, etc.).

\section{Nostalgia and Emotions}

Nostalgia refers to "a positively toned evocation of a lived past" (Davis 1979, p. 18). Gabriel (1993, p. 119), building on Davis' (1979) work, describes nostalgia as a sentimental "attachment to the organization that was, [like a] yearning for the past." Organizational research demonstrates that nostalgia is not only individually experienced, but also a social phenomenon (Miller et al. 2018). That is, the experience of nostalgia, like other emotive experiences, is often shared among social groups such as organizations (De Rivera 1992). Hence, nostalgia can be a constitutive element of a collective identity. It juxtaposes an idealized interpretation of the past with a present that is found impoverished and lacking (Gabriel 1993). For instance, organizational members might nostalgically recall the pioneering golden days, the founder, or the physical buildings of the organization now relocated.

Nostalgia has been introduced as an approach to investigate the complexity and ambivalence of emotional feelings and experience in organizations (Gabriel 1993). The topic of emotions in social and organizational life has only recently gained traction in organization theory (see the overview in Zietsma et al. 2019). In CSR research, an emerging stream considers emotions (such as guilt and shame) as drivers for CSR engagement. However, Gond et al. (2017, p. 233) observed that "surprisingly little is known about how affective processes shape CSR evaluations." Hence, we suggest that studying nostalgia in the context of long-term CSR engagements might be a path to fill this gap. For instance, Gabriel (1993) posits that social functions (e.g., qualities as mutuality, caring, altruism) that become lost over time can attract nostalgic feelings in organizations. Nostalgia may well be a central emotive experience that triggers the restoration or upholding of CSR practice once dropped. Such longing for the past may also be a catalyst to the sort of institutional innovation, experimentation, and adaptation described by Hielscher and Husted (2019). In all, we suggest that studying the emotional evocation of history in the present offers a novel approach to investigate the role of emotions in contemporary CSR practice.

\section{Conclusion}

Only future historians of the CSR field can tell whether a "historic turn" in the CSR field, as proclaimed by Godfrey et al. (2016), is underway or not. Our review, however, is evidence that the collective effort of organizational historians and scholars of CSR and business ethics has resulted in a remarkable interdisciplinary integration of the past, history, and CSR thinking. This essay is a snapshot of these efforts at this moment. Our umbrella term historical CSR embraces, at least, three distinct theoretical perspectives that we called past-of-CSR, past-in-CSR, and past-as-CSR. Each perspective draws from and contributes to a different understanding of the relevance and meaning of the past and history for CSR scholarship and practice. We eagerly await the history's judgement — and that of other scholars—as to the usefulness of these distinctions as a lens for future work.

\section{References}

Abend, G. (2013). The origins of business ethics in American universities, 1902-1936. Business Ethics Quarterly, 23(2), 171-205.

Acosta, P., \& Pérezts, M. (2019). Unearthing sedimentation dynamics in political CSR: The case of Colombia. Journal of Business Ethics, 155(2), 425-444.

Acquier, A., Gond, J.-P., \& Pasquero, J. (2011). Rediscovering Howard R. Bowen's legacy: The unachieved agenda and continuing relevance of social responsibilities of the businessman. Business Society, 50(4), 607-646.

Alvesson, M. (1998). The business concept as a symbol. International Studies of Management and Organisation, 28(3), 86-108.

Antal, A. B., Oppen, M., \& Sobczak, A. (2009). (Re)discovering the social responsibility of business in Germany. Journal of Business Ethics, 89(Suppl. 3), 285-301. 
Anteby, M., \& Molnar, V. (2012). Collective memory meets organizational identity: Remembering to forget in a firm's rhetorical history. Academy of Management Journal, 55(3), 515-540.

Balmer, J. M. T. (1998). Corporate identity and the advent of corporate marketing. Journal of Marketing Management, 14(8), 963-996.

Barnett, M. L., Jermier, J. M., \& Lafferty, B. A. (2006). Corporate reputation: The definitional landscape. Corporate Reputation Review, 9(1), 26-38.

Barros, A., \& Taylor, S. (2018). Think tanks, business and civil society: The ethics of promoting pro-corporate ideologies. Journal of Business Ethics. https://doi.org/10.1007/s10551-018-4007-y.

Beets, S. D. (2011). Critical events in the ethics of U.S. corporation history. Journal of Business Ethics, 102(2), 193-219.

Bengtsson, E. (2008). A history of Scandinavian socially responsible investing. Journal of Business Ethics, 82(4), 969-983.

Booth, C., Clark, P., Delahaye, A., Procter, S., \& Rowlinson, M. (2007). Accounting for the dark side of corporate history: Organizational culture perspectives and the Bertelsmann case. Critical Perspectives on Accounting, 18(6), 625-644.

Brown, S., Kozinets, R. V., \& Sherry, J. F. (2003). Teaching old brands new tricks: Retro branding and the revival of brand meaning. Journal of Marketing, 67(3), 19-33.

Brunninge, O., \& Fridriksson, H.-V. (2017). "We have always been responsible": A social memory approach to responsibility in supply chains. European Business Review, 29(3), 372-383.

Carroll, A. B., Lipartito, K., Post, J. E., Werhane, P. H., \& Goodpaster, K. E. (2012). Corporate responsibility: The American experience. New York: Cambridge University Press.

Carter, S. M., \& Deephouse, D. L. (1999). Tough talk and soothing speech: Managing reputations for being tough and for being good. Corporate Reputation Review, 2(4), 308-332.

Chun, R. (2005). Corporate reputation: Meaning and measurement. International Journal of Management Reviews, 7(2), 91-109.

Coraiola, D. M., \& Derry, R. (2019). Remembering to forget: The historic irresponsibility of U.S. big tobacco. Journal of Business Ethics. https://doi.org/10.1007/s10551-019-04323-4.

Coraiola, D. M., Foster, W. M., \& Suddaby, R. (2015). Varieties of history in organization studies. The Routledge companion to management and organizational history (pp. 206-221). Oxon, UK: Routledge.

Cummings, S., Bridgman, T., Hassard, J., \& Rowlinson, M. (2017). A new history of management. Cambridge, UK: Cambridge University Press.

Davis, F. (1979). Yearning for yesterday: A sociology of nostalgia. New York: Free Press.

De Baets, A. (2009). Responsible history. New York: Berghahn Books.

De Rivera, J. (1992). Emotional climate: Social structure and emotional dynamics. International Review of studies on Emotion, 2, 197-218.

Djelic, M.-L., \& Etchanchu, H. (2017). Contextualizing corporate political responsibilities: Neoliberal CSR in historical perspective. Journal of Business Ethics, 142(4), 641-661.

Fombrun, C. J. (1996). Reputation: Realizing value from the corporate image. Boston: Harvard Business School Press.

Fox, M., Tost, L. P., \& Wade-Benzoni, K. A. (2010). The legacy motive: A catalyst for sustainable decision making in organizations. Business Ethics Quarterly, 20(2), 153-185.

Gabriel, Y. (1993). Organizational nostalgia: Reflections on "the Golden Age”. In S. Fineman (Ed.), Emotions in organizations (pp. 118-141). London: SAGE

Gill, M. J., Gill, D. J., \& Roulet, T. J. (2018). Constructing trustworthy historical narratives: Criteria, principles and techniques. British Journal of Management, 29(1), 191-205.

Godfrey, P. C., Hassard, J., O’Connor, E. S. O., Rowlinson, M., \& Ruef, M. (2016). What is organizational history? Toward a creative synthesis of history and organization studies. Academy of Management Review, 41(4), 590-608.

Gond, J. P., El Akremi, A., Swaen, V., \& Babu, N. (2017). The psychological microfoundations of corporate social responsibility: A person-centric systematic review. Journal of Organizational Behavior, 38(2), 225-246.

Haigh, G. (2007). Asbestos house: The secret history of James Hardie industries. London: Scribe Publishers.

Hatch, M. J., \& Schultz, M. (2017). Toward a theory of using history authentically. Administrative Science Quarterly, 62(4), 657-697.

Hielscher, S., \& Husted, B. W. (2019). Proto-CSR before the industrial revolution: institutional experimentation by medieval miners' guilds. Journal of Business Ethics. https://doi.org/10.1007/s1055 1-019-04322-5.

Husted, B. W. (2015). Corporate social responsibility practice from 1800-1914: Past initiatives and current debates. Business Ethics Quarterly, 25(1), 125-141.

Ihlen, Ø., \& von Weltzien Hoivik, H. (2013). Ye olde CSR: The historic roots of corporate social responsibility in Norway. Journal of Business Ethics, 127(1), 109-120.

Janssen, C. I. (2013). Corporate historical responsibility (CHR): Addressing a corporate past of forced labor at Volkswagen. Journal of Applied Communication Research, 41(1), 64-83.

Kaplan, R., \& Kinderman, D. (2017). The business-led globalization of CSR: Channels of diffusion from the United States into Venezuela and Britain, 1962-1981. Business \& Society. https://doi. org/10.1177/0007650317717958.

Kipping, M., \& Üsdiken, B. (2014). History in organization and management theory: More than meets the eye. The Academy of Management Annals, 8(1), 1-83.

Maclean, M., Harvey, C., \& Clegg, S. R. (2016). Conceptualizing historical organization studies. Academy of Management Review, 41(4), 609-632.

Mahon, J. F. (2002). Corporate reputation: A research agenda using strategy and stakeholder literature. Business \& Society, 41(4), 415-445.

Manning, R. C. (1984). Corporate responsibility and corporate personhood. Journal of Business Ethics, 3(1), 77-84.

Marens, R. (2010). Destroying the village to save it: Corporate social responsibility, labour relations, and the rise and fall of American hegemony. Organization, 17(6), 743-766.

Marens, R. (2012). Generous in victory? American managerial autonomy, labour relations and the invention of corporate social responsibility. Socio-Economic Review, 10(1), 59-84.

Marens, R. (2013). What comes around: The early 20th century American roots of legitimating corporate social responsibility. Organization, 20(3), 454-476.

Marens, R. (2018). Laying the foundation: Preparing the field of business and society for investigating the relationship between business and inequality. Business \& Society, 57(6), 1252-1285.

Mena, S., Rintamäki, J., Fleming, P., \& Spicer, A. (2016). On the forgetting of corporate irresponsibility. Academy of Management Review, 41(4), 720-738.

Miller, D. (2001). Distributing responsibilities. The Journal of Political Philosophy, 9(4), 453-471.

Miller, K. D., Gomes, E., \& Lehman, D. W. (2018). Strategy restoration. Longe Range Planning. https://doi.org/10.1016/j. lrp.2018.10.005.

Munslow, A. (2006). Deconstructing history (2nd ed.). London, UK: Routledge.

Parker, O. N., Krause, R. A., \& Devers, C. E. (2019). How firm reputation shapes managerial discretion. Academy of Management Review, 44(2), 254-278.

Perchard, A., MacKenzie, N. G., Decker, S., \& Favero, G. (2017). Clio in the business school: Historical approaches in strategy, 
international business and entrepreneurship. Business History, 59(6), 904-927.

Rhee, M., \& Haunschild, P. R. (2006). The liability of good reputation: A study of product recalls in the US automobile industry. Organization Science, 17(1), 101-117.

Rowlinson, M., Hassard, J., \& Decker, S. (2014). Research strategies for organizational history: A dialogue between historical theory and organization theory. Academy of Management Review, 39(3), $250-274$

Schrempf, J. (2011). Nokia Siemens networks: Just doing business or supporting an oppressive regime? Journal of Business Ethics, 103(1), 95-110.

Schrempf-Stirling, J., \& Palazzo, G. (2016). Upstream corporate social responsibility: The evolution from contract responsibility to full producer responsibility. Business \& Society, 55(4), 491-527.

Schrempf-Stirling, J., Palazzo, G., \& Phillips, R. A. (2016). Historic corporate social responsibility. Academy of Management Review, 41(4), 700-719.

Smith, A., \& Johns, J. (2019). Historicizing modern slavery: free-grown sugar as an ethics-driven market category in nineteenth-century Britain. Journal of Business Ethics. https://doi.org/10.1007/s1055 1-019-04318-1.

Stinchcombe, A. L. (1965). Social structure and organizations. In J. G. March (Ed.), Handbook of organizations (pp. 142-193). Chicago: Rand McNally.

Stutz, C. (2018). History in corporate social responsibility: Reviewing and setting an agenda. Business History. https://doi. org/10.1080/00076791.2018.1543661.

Stutz, C., \& Sachs, S. (2018). Facing the normative challenges: The potential of reflexive historical research. Business \& Society, 57(1), 98-130.

Stutz, C., \& Schrempf-Stirling, J. (2019). Using the past responsibly: What responsible managers and management academics can learn from historians' professional ethics. In O. Laasch, D. Jamali, R. E. Freeman, \& R. Suddaby (Eds.), Research handbook of responsible management (pp. 1-23). Cheltenham, UK: Edward Elgar.

Suddaby, R. (2016). Toward a historical consciousness: Following the historic turn in management thought. M@n@gement, 19(1), $46-60$.

Suddaby, R., \& Foster, W. M. (2017). History and organizational change. Journal of Management, 43(1), 19-38.

Suddaby, R., Foster, W. M., \& Quinn-Trank, C. (2016). Organizational re-membering: Rhetorical history as identity work. In M. G. Pratt, M. Schultz, B. E. Ashforth, \& D. Ravasi (Eds.), The Oxford handbook of organizational identity (pp. 297-316). Oxford, UK: Oxford University Press.

Suddaby, R., Foster, W. M., \& Trank, C. Q. (2010). Rhetorical history as a source of competitive advantage. Advances in Strategic Management, 27, 147-173.

Sydow, J., Schreyögg, G., \& Koch, J. (2009). Organizational path dependence: Opening the black box. Academy of Management Review, 34(4), 689-709.

Treviño, L. K., Weaver, G. R., \& Brown, M. E. (2008). It's lovely at the top: Hierarchical levels, identities, and perceptions of organizational ethics. Business Ethics Quarterly, 18(2), 233-252.
Urde, M., Greyser, S. A., \& Balmer, J. M. T. (2007). Corporate brands with a heritage. Journal of Brand Management, 15(1), 4-19.

Van Buren, H. J. (2008). Fairness and the main management theories of the twentieth century: A historical review, 1900-1965. Journal of Business Ethics, 82(3), 633-644.

Van Lent, W., \& Durepos, G. (2019). Nurturing the historic turn: "History as theory" versus "history as method". Journal of Management History. https://doi.org/10.1108/JMH-03-2019-0017.

Van Lent, W., \& Smith, A. D. (2019). Using versus excusing: The Hudson's Bay Company's long-term engagement with its (problematic) past. Journal of Business Ethics. https://doi.org/10.1007/ s10551-019-04320-7.

Vanhamme, J., \& Grobben, B. (2009). "Too good to be true!": The effectiveness of CSR history in countering negative publicity. Journal of Business Ethics, 85(SUPPL. 2), 273-283.

Wade-Benzoni, K. A., Sondak, H., \& Galinsky, A. D. (2010). Leaving a legacy: Intergenerational allocations of benefits and burdens. Business Ethics Quarterly, 20(1), 7-34.

Wadhwani, R. D., \& Bucheli, M. (2014). The future of the past in management and organization studies. In M. Bucheli \& R. D. Wadhwani (Eds.), Organizations in time: History, theory, methods (pp. 3-32). Oxford, England: Oxford University Press.

Wadhwani, R. D., Suddaby, R., Mordhorst, M., \& Popp, A. (2018). History as organizing: Uses of the past in organization studies. Organization Studies, 39(12), 1663-1683.

Walker, K. (2010). A systematic review of the corporate reputation literature: Definition, measurement, and theory. Corporate Reputation Review, 12(4), 357-387.

Walsh, J. P., \& Ungson, G. R. (1991). Organizational memory. Academy of Management Review, 16(1), 57-91.

Warren, R. C., \& Tweedale, G. (2002). Business ethics and business history: Neglected dimensions in management education. British Journal of Management, 13, 209-219.

Werhane, P. (1985). Persons, rights, \& corporations. Englewood Cliffs, NJ: Prentice- Hall.

Wheeler, D., Fabig, H., \& Boele, R. (2002). Paradoxes and dilemmas for stakeholder responsive firms in the extractive sector: Lessons from the case of Shell and the Ogoni. Journal of Business Ethics, 39(3), 297-318.

Whetten, D. A. (1997). Theory development and the study of corporate reputation. Corporate Reputation Review, 1, 26-34.

Young, I. M. (2006). Responsibility and global justice: A social connection model. Social Philosophy and Policy, 23(1), 102-130.

Zietsma, C., Toubiana, M., Voronov, M., \& Roberts, A. (2019). Emotions in organization theory. Cambridge, UK: Cambridge University Press.

Publisher's Note Springer Nature remains neutral with regard to jurisdictional claims in published maps and institutional affiliations. 